\title{
ANGIOGENESIS AS AN INDICATOR OF METASTATIC POTENTIAL IN PAPILLARY THYROID CARCINOMA
}

\author{
Elaine Stabenow, Marcos Roberto Tavares, Alexandre Muxfeldt Ab'Saber, Edwin \\ Roger Parra-Cuentas, Leandro Luongo de Matos, Esmeralda Miristene Eher, \\ Vera Luiza Capelozzi, and Alberto Rosseti Ferraz
}

Stabenow E, Tavares MR, AM Ab'Saber, ER Parra-Cuentas, LL de Matos, Eher EM et al. Angiogenesis as an indicator of metastatic potential in papillary thyroid carcinoma. Clinics. 2005;60(3):233-40.

Angiogenesis is new blood vessel formation, a process that can lead to tumor development. Microvessel count has been correlated to metastasis in some neoplasias.

PURPOSE: To determine if measurement of microvessel density is useful in predicting metastasis to the cervical lymph node and prognosis in patients with papillary thyroid carcinoma.

METHODS: A retrospective analysis was performed in 30 patients that had undergone total thyroidectomy. They were divided in 2 groups of 15 patients - with and without metastatic disease. Immunohistochemistry was used to detect expression of CD34 in archival paraffin-embedded papillary thyroid tumors, and microvessel density was calculated based on it. Association between microvessel density and the presence of metastasis, according to histological subtype, disease recurrence, and AMES prognostic index groups was determined through statistical analysis.

RESULTS: The median microvessel density for the patient group without metastasis $\left(200.0\right.$ microvessels $\left./ \mathrm{mm}^{2}\right)$ was apparently, but not significantly, less than that observed among metastatic disease patients $\left(254.4\right.$ microvessels $\left./ \mathrm{mm}^{2}\right)(P=.20)$. When papillary carcinoma subtypes were analyzed, this difference became significant $(P=.02)$. The follicular variant exhibited a greater microvessel density than the other subtypes, independent of metastasis presence. There was an apparent, but not significant, tendency for a larger median microvessel density in the group of patients that presented recurrence (294.4 microvessels $/ \mathrm{mm}^{2}$ vs 249.6 microvessels $/ \mathrm{mm}^{2}, P=.11$ ). There was no relationship between risk level and microvessel density: in the low- and high-risk groups, the median MVD was 304.0 microvessels $/ \mathrm{mm}^{2}$ and 229.6 microvessels $/ \mathrm{mm}^{2}$, respectively $(P=.27)$.

CONCLUSIONS: The results suggest that angiogenesis is more intense among metastatic tumors in the classic and the tall cell variants, indicating that microvessel count can be an indicator of the potential for metastasis in these subtypes of papillary thyroid carcinoma. Patients that developed recurrent disease had a tendency to exhibit higher angiogenesis; however, there was no association between microvessel density and the AMES prognostic index.

KEYWORDS: Papillary thyroid carcinoma. Angiogenesis. CD34. Node metastasis. Prognosis.

Papillary thyroid carcinoma is classified as a well-differentiated carcinoma, and it is the most common malignant neoplasia of endocrine origin. Although it usually has a good prognosis and is curable in most well-treated cases,

Head and Neck Surgery Department and Pathology Department, Hospital das Clínicas, Faculty of Medicine, University of São Paulo - São Paulo/SP, Brazil.

E-mail: stabenow@hotmail.com

Received for publication on November 22, 2004

Accepted for publication on February 14, 2005. recurrent disease can reach $20 \%$, in the presence of local invasion and metastasis, while management in these cases is still a challenge. Thus, a considerable number of research projects has been carried out to identify prognostic factors that would make it possible to classify these patients into risk groups according to a prognostic scoring system. ${ }^{1-6}$

Cervical lymph node involvement in papillary thyroid carcinoma has not been considered a bad prognostic factor. In spite of this, there are reports of higher mortality and local recurrence when cervical lymph node involvement 
occurs in older patients. ${ }^{1,4,5}$ Moreover, neck dissection is necessary in such cases, which, requires in the least more surgical procedure. These facts, along with the findings that even low-risk tumors can develop into aggressive disease, demonstrate that there is a need to develop methods to better characterize the well-differentiated carcinoma, which would help achieve an adequate therapeutic approach. ${ }^{6}$ Biological markers capable of identifying increased risk of metastasis development can contribute to an objective recognition of high-risk tumors.

Angiogenesis, the generation of new blood vessels, is crucial for tumor growth and metastasis development. In neoplastic diseases, it is stimulated by factors produced by tumor cells. Biological markers related to this process could be useful for diagnosis and identification of the prognosis in malignant diseases. Evidence that antiangiogenic therapy inhibits growth of some tumors attests to the importance of studying such markers. ${ }^{7,8}$

Some angiogenic factors-fibroblast growth factors (FGF) and vascular endothelial growth factors(VEGF) have been identified that undergo increased expression by several kinds of solid tumors. ${ }^{9-12}$ It is also known that the number of new blood vessels is greater in neoplastic tissue than in normal tissue. ${ }^{6,13,14}$ Metastatic thyroid tumors have a greater immunohistochemical expression of VEGF, ${ }^{15}$ and an altered expression of genes associated with angiogenesis was found in metastatic follicular thyroid carcinoma. ${ }^{16}$

The first reports of a relationship between metastasis and the number of tumor blood vessels were by Srivastava ${ }^{17}$ in 1988, in melanoma studies, and Weidner ${ }^{18}$ in 1992, who compared microvessel density (MVD) with breast carcinoma prognosis. Since then, studies have indicated the possibility of a correlation between microvessel count, which is a measure of tumor angiogenesis, and formation of regional metastasis in different malignant neoplasms. ${ }^{19,20}$ However, in thyroid carcinoma, the value of MVD as a prognostic indicator and its role in metastasis development has remained controversial.

The number of microvessels in undifferentiated thyroid tumors was found to be very low, and only in medullary carcinoma was the highest MVD a significant prognostic factor. ${ }^{21}$ Microvessel density was higher in well-differentiated thyroid carcinoma when compared to adjacent normal thyroid tissue, but was not correlated to poor outcome. ${ }^{6}$ Similar results were found in follicular neoplasms. ${ }^{22}$ On the other hand, other investigators found that MVD can be a significant prognostic indicator in papillary thyroid carcinoma. ${ }^{23,24}$

Our purpose was to compare MVD between 2 homogeneous groups of patients with papillary thyroid carcinomawith or without cervical node metastatic disease - to de- termine if angiogenesis measurement can indicate the metastatic potential and prognosis for papillary thyroid carcinoma.

\section{METHODS}

Following the approval of the Institutional Committee on Ethics and Research we studied 30 patients treated for papillary thyroid carcinoma who had undergone thyroidectomy during the period of January 1997 to February 1998. They were distributed into 2 groups:

- Group 1: 15 patients without metastasis at diagnosis;

- Group 2: 15 patients with metastasis at diagnosis.

The following background data were collected: physical examination of the cervical area; preoperative exams; treatment carried out (extent of the operation, complementary radio iodine therapy); pathological features; postoperative exams; and clinical evolution.

\section{Morphological evaluation and immunohistochemistry assay}

After a histological review, the papillary carcinomas and their histological subtypes were classified according to the $\mathrm{AFIP}^{25}$ criteria. A representative tumor area was considered for immunohistochemical analysis.

Immunohistochemistry was performed on thin sections ( $3 \mu \mathrm{m})$ of previously formalin-fixed and paraffin-embedded tissues, following the standard avidin-biotin-peroxidase complex method. Tumor sections were stained with antiendothelial cell antibody, the mouse monoclonal antibody CD34 (Lyophilized Monoclonal - NCL-END, Novocastra ${ }^{\circledR}$, 1:600 dilution). Immunoreaction was visualized using diaminobenzidine (DAB) as the chromogen.

Areas of greater concentration of stained vessels (hot spots) were identified at low magnification. Ten fields at 400x magnification were then studied within these areas, and the immunohistochemistry index was determined by the point counting ${ }^{26}$ technique, making it possible to obtain the number of microvessels stained positively in the studied tumor area.

\section{Prognostic evaluation}

Since there is no mortality related to papillary carcinoma, only a Kaplan-Meyer disease-free survival study was performed. We also classified all patients into risk groups according to the $\mathrm{AMES}^{4}$ prognostic index, where " $\mathrm{A}$ " represents age, "M" distant metastasis, "E" extrathyroidal extension, and " $\mathrm{S}$ " the largest diameter of the tumor. Age is the prognostic factor related to the patient, while all others 
Table 1 - Risk groups according to AMES ${ }^{4}$ prognostic index.

\begin{tabular}{lcccc}
\hline Group & Low Risk & \multicolumn{2}{c}{ Intermediate Risk } & High Risk \\
\hline Patient & $<45$ years old & $<45$ years old & $\geq 45$ years old & $\geq 45$ years old \\
Tumor & Low Risk & High Risk & Low Risk & High Risk \\
\hline
\end{tabular}

constitute factors related to the tumor which can be classified as:

- Low-risk: absence of distant metastasis and of extrathyroidal extension; largest tumor diameter $\leq 40 \mathrm{~mm}$;

- High-risk: presence of distant metastasis, or extrathyroidal extension, or largest tumor diameter $>40 \mathrm{~mm}$.

Patients were finally distributed into 3 risk groups as shown in Table 1.

\section{Results evaluation}

For statistical analysis, the software package SPSS ${ }^{\circledR} 11.0$ for Windows ${ }^{\circledast} 2000$ was used, and a 5\% $(P<.05)$ significance level was adopted. Comparison between classified variables was assessed by the Fisher exact test. Since the test of normality revealed that this study group was not parametric $(P=.078)$, comparison between the medians of the continuous variables was performed through Mann-Whitney and Kruskal-Wallis tests. For correlation studies, the Spearman rank correlation test was applied.

\section{RESULTS}

\section{Patients}

The average age was $46.7 \pm 18.9$ years (mean \pm SD; range, 14-75 years). There was no difference in age between groups: In group 1 , the average age was $47.9 \pm 20$ years, and in group 2 , it was $45.5 \pm 18.3$ years $(P=.73)$. Only 1 man was included in the study, belonging to group 2 .

No difference was detected between groups regarding physical examination, nor regarding the presence of antithyroid antibodies.

Total thyroidectomy was performed in all cases, com- plemented by neck dissection if lymph node metastasis was present. Whole body scintigraphy with iodine was carried out in all but 1 of the cases. No patient presented distant metastasis at diagnosis.

The median follow-up time was $59.4 \pm 14$ months (range 12-72 months). The postoperative marker of recurrence was the curve of the thyroglobulin serum level. Recurrence occurred in $6(20 \%)$ patients in an average time of 26.7 months. Recurrences occurred mainly in group $2(P=.04)$. The Kaplan-Meyer disease-free survival was $71 \%$ in 5 years.

\section{Morphologic evaluation}

The papillary thyroid carcinoma histological subtypes found were: classic papillary carcinoma in 19 cases (63.3\%); tall cell in 5 cases (16.7\%); and follicular in 6 cases $(20 \%)$.

The average tumor size was $23.83 \pm 2.5 \mathrm{~mm}$. Microcarcinomas $(\leq 10.0 \mathrm{~mm})$ represented $17 \%$ of the tumors, while $73 \%$ exhibited sizes between 11 and $40 \mathrm{~mm}$ at the largest diameter; $10 \%$ of the tumors were greater than $40 \mathrm{~mm}$ in diameter. There was no difference in size between groups 1 and $2(P=.79)$.

When we analyzed characteristics of local invasion, we found that $13(43.3 \%)$ of tumors exhibited extrathyroidal extension, $10(33.3 \%)$ vascular invasion, 7 (23.3\%) perineural invasion, 12 (40\%) lymphatic invasion, and 19 $(63.3 \%)$ were multicentric tumors.

\section{Microvessel density analysis (MVD)}

The pattern of CD34 antibody expression in papillary thyroid carcinoma can be seen in Figure 1. There is posi-

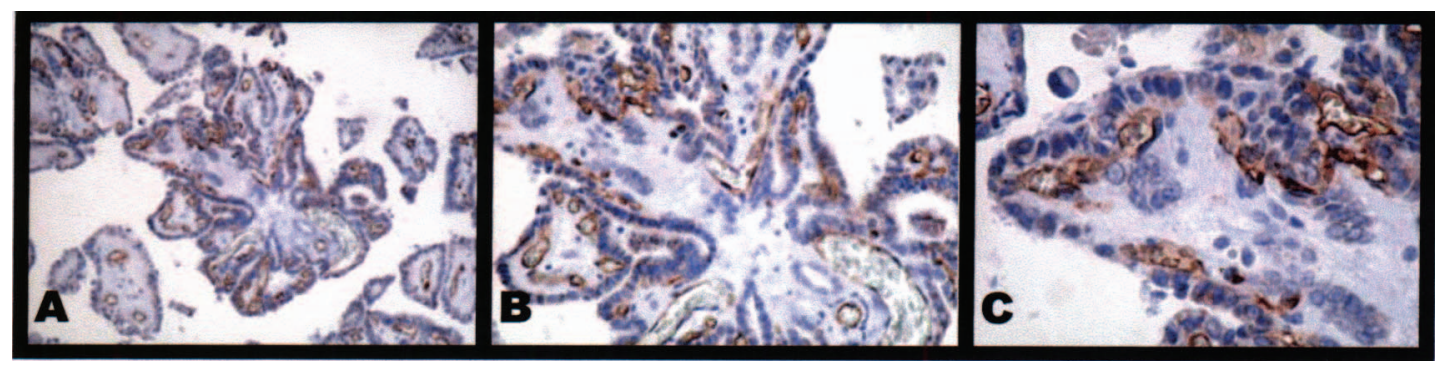

Figure 1 - CD34 staining aspect in papillary thyroid carcinoma. 40x (A), 100x (B) and 400x (C) magnification. The brown-dark represents endothelial cells stained by CD34 antibody in blood vessels of the papillary fibrovascular axis. 
tive staining in the cytoplasm of endothelial cells, mainly inside the fibrovascular axis of the formed papillae.

The median MVD for all patients was 249.6 microvessels $/ \mathrm{mm}^{2}$ (range, $72.0-622.4$ microvessels $/ \mathrm{mm}^{2}$ ). In group 1, the median MVD was 200.0 microvessels $/ \mathrm{mm}^{2}$ (range, 72.0-622.4 microvessels $/ \mathrm{mm}^{2}$ ), and in group 2, it was 254.4 microvessels $/ \mathrm{mm}^{2}$ (range, 179.2-544.0 microvessels/ $\left.\mathrm{mm}^{2}\right)(P=.20)$.

A high MVD was found in the follicular subtype (median of 354.4 microvessels $/ \mathrm{mm}^{2}$ ) when compared to other histological subtypes (tall cell, median MVD of 179.2 microvessels $/ \mathrm{mm}^{2}$; classic subtype, median MVD of 236.8 microvessels $/ \mathrm{mm}^{2}$ ), independent of the presence of metastasis (Figure 2). In addition, the number of follicular subtypes was larger in the patient group without lymph node metastasis (Table 2). Therefore, when we analyzed only classic and tall cell variants in both groups, the median MVD was smaller in group 1 (179.0 microvessels $/ \mathrm{mm}^{2}$; range, $72.0-436.8$ microvessels $\left./ \mathrm{mm}^{2}\right)$ than in group $2(272.0$ microvessels $/ \mathrm{mm}^{2}$; range, 179.2-544.0 microvessels $/ \mathrm{mm}^{2}$ ) $(P=.02)$, as shown in Figure 3.

Regarding patient age, the median MVD was 252.0
Table 2 - The MDV (microvessels $/ \mathrm{mm}^{2}$ ) median of risk groups according to $\mathrm{AMES}^{4}$ prognostic index.

\begin{tabular}{lll}
\hline Risk Groups & Number of Cases & MDV Median* \\
\hline Low Risk & $8(27 \%)^{* *}$ & 304,0 \\
Intermediate Risk & $14(46 \%)^{* *}$ & 224,8 \\
High Risk & $8(27 \%)^{* *}$ & 229,6 \\
\hline
\end{tabular}

* microvessels $/ \mathrm{mm}^{2}, \mathrm{p}=0,27$; Kruskal-Wallis test.

** percentage of patients total.

microvessels $/ \mathrm{mm}^{2}$ in the group with ages less than 45 years and 229.6 microvessels $/ \mathrm{mm}^{2}$ in the group with ages greater than 45 years $(P=.26)$. There was no correlation between age and MVD (Spearman correlation coefficient $=-0.28, P$ $=.14)$.

The distribution of patients according to the AMES index, and the median MVD of each risk group, are presented in Table 3.

The median MVD in the patient group that developed recurrence was 294.4 microvessels $/ \mathrm{mm}^{2}$ and for those who did not experience recurrence was 249.6 microvessels $/ \mathrm{mm}^{2}$ $(P=.11)$.

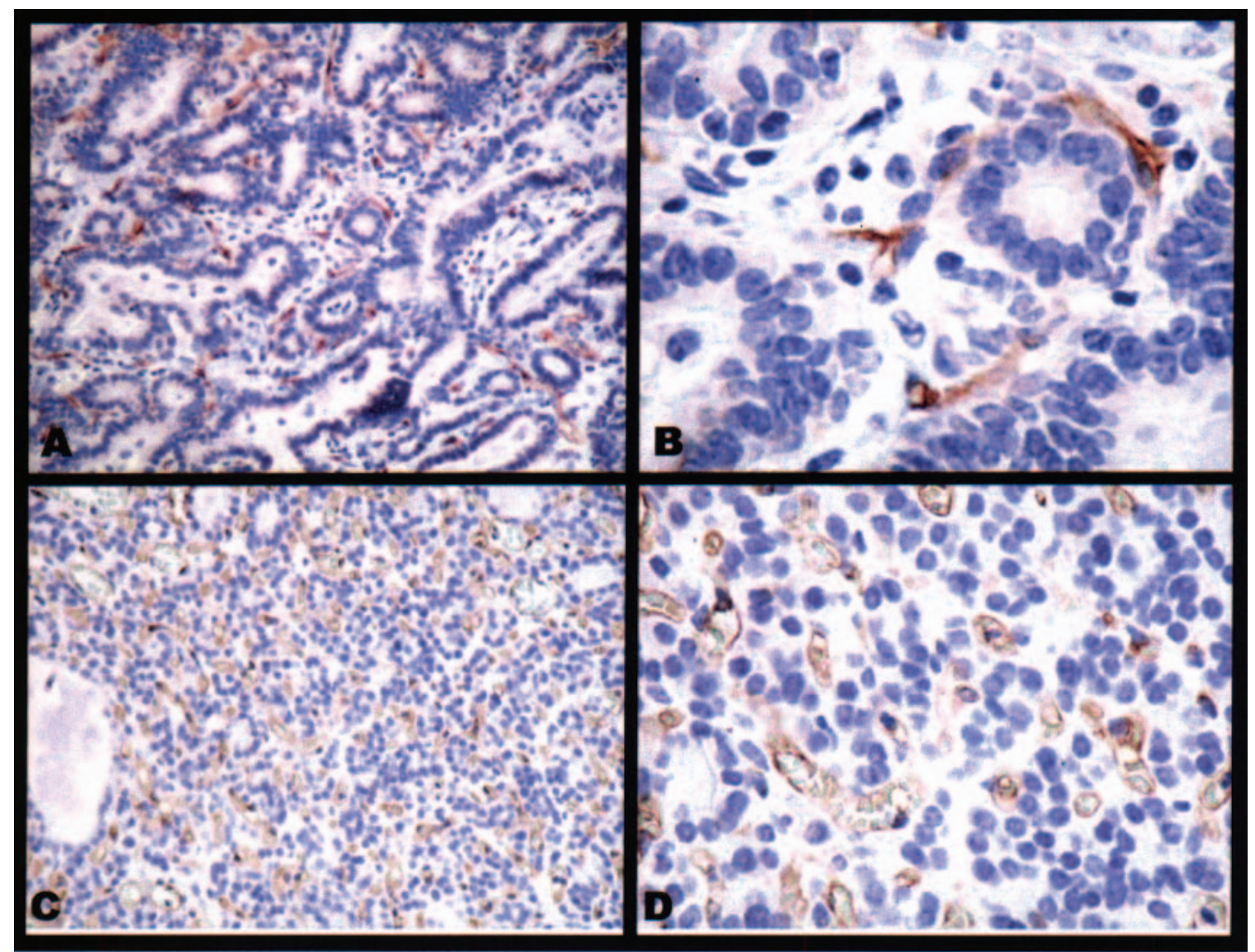

Figure 2 - The CD34 antibody expression in classic papillary carcinoma subtype, at 40X (A) and 400x (B) magnification; and in follicular one, at 40x (C) and 400x (D) magnification showing the higher number of microvessels in follicular papillary carcinoma subtype. 

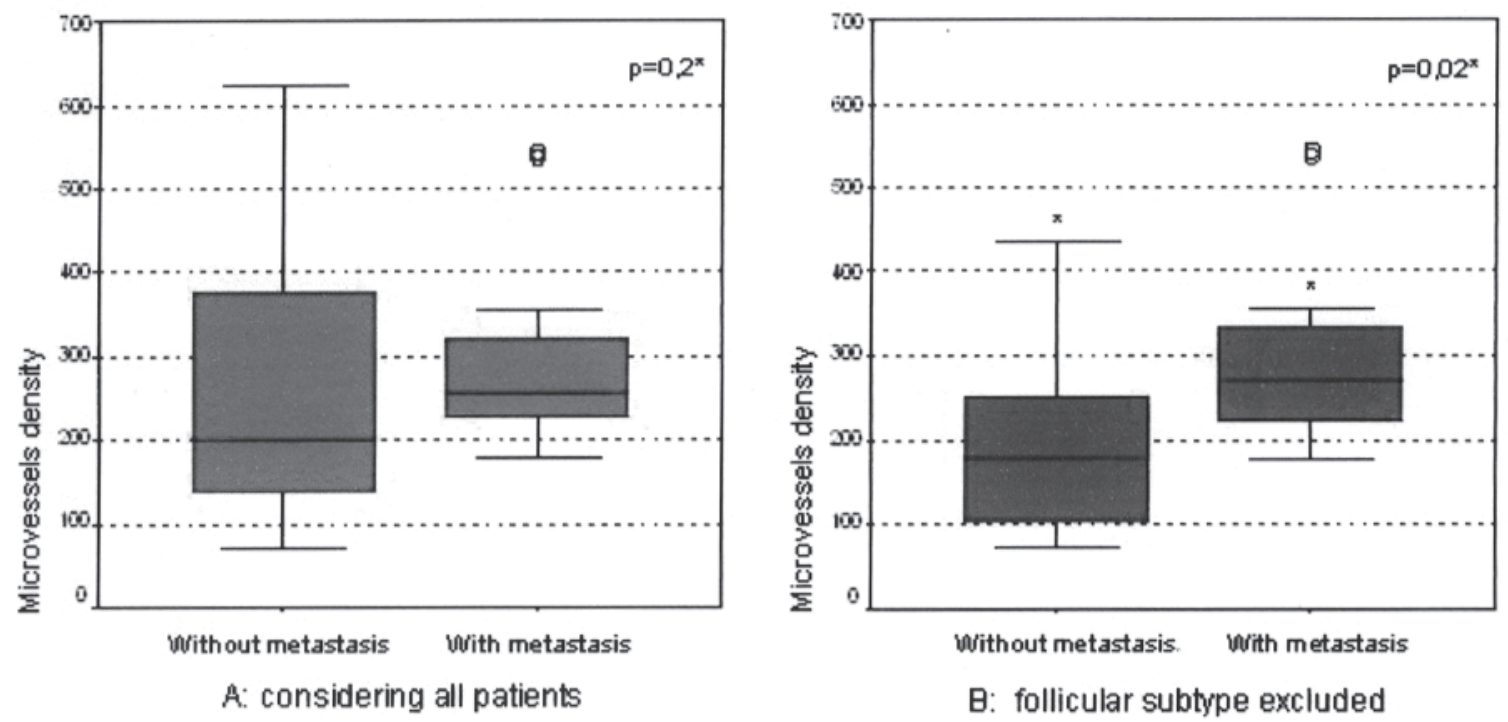

Figure 3 - MVD (microvessels $/ \mathrm{mm}^{2}$ ) comparison between groups without and with metastasis, considering all patients (A) and after follicular subtype exclusion in both groups (B).

* Mann-Whytney test.

Table 3 - The MDV median of risk groups according to AMES $^{4}$ prognostic index.

\begin{tabular}{lcc}
\hline Risk groups & Number of cases & MVD median* \\
\hline Low risk & $8(27 \%)$ & 304.0 \\
Intermediate risk & $14(46 \%)$ & 224.8 \\
Higth risk & $8(8 \%)$ & 229.6 \\
Total & $30(100 \%)$ & 249.6 \\
\hline
\end{tabular}

* microvessels $/ \mathrm{mm}^{2}, \mathrm{p}=0,27$; Kruskal-Wallis test

\section{DISCUSSION}

It is important to determine the prognosis case by case in the process of choosing the appropriate treatment. Most patients present extremely favorable evolution, which is sometimes not related to the extent of surgical resection. However, some cases have a poor outcome and previously there have been no objective criteria to separate them.

The importance of angiogenesis has long been described in tumor progression and metastasis formation. ${ }^{7}$ Methods that enable quantification of angiogenesis have been developed to evaluate its role in the prognosis of different tumors. Regarding thyroid carcinoma, quantification of angiogenesis has been reported in a few studies. In Brazil, the expression of CD34 in follicular thyroid neoplasm was studied in a single study. ${ }^{22}$

This research analyzed MVD in thyroid papillary carcinoma in a case-control (metastatic disease vs no metastatic disease) study using CD34 immunostaining. Other markers can be used, but CD34 has proved to be better than factor VIII and CD31 in previously paraffin-embedded tissues..$^{27,28}$
In this series, the findings regarding MVD were tested statistically, increasing the reliability of the conclusions.

There was similarity among the groups, regarding patient age, tumor nodule size, and applied treatment. The frequency of recurrent disease was higher in cases that developed metastases, similar to that found by other authors. ${ }^{2,3,5}$

We found a median MVD of 249.6 microvessels $/ \mathrm{mm}^{2}$, which is similar to that $\left(202.1\right.$ microvessels $\left./ \mathrm{mm}^{2}\right)$ observed by Livolsi and Asklen. ${ }^{13}$

When groups with and without metastasis were considered, we noticed that there was a tendency to higher angiogenesis in the metastatic disease group (group 2), as has been shown by other authors. ${ }^{6,13}$ Evaluation considering only classic and tall cells subtypes had significantly greater MVD in group 2. This means that quantitative angiogenesis analysis can be considered as a tool for identifying the higher potential of metastasis development in those histological subtypes. To investigate this hypothesis in the follicular variant, other studies are necessary involving larger numbers of this tumor subtype. Several studies have shown that follicular carcinoma has a higher MVD than papillary carcinoma, ${ }^{6,21,29,30}$ a point which had already been documented in studies with VEGF. ${ }^{16}$ It is interesting to note that the follicular variant of papillary carcinoma had microvessel patterns that were similar to those described in follicular carcinoma, and in spite of the high MVD, there was no correlation with the occurrence of lymph node metastasis. This finding is in agreement with the fact already demonstrated $^{1}$ that follicular carcinoma has a greater tendency towards hematogenic metastasis. On the other hand, the high MVD developed in the follicular variant suggests 
that angiogenesis quantification can aid in differential diagnosis of follicular neoplasms, a point which also needs to be studied in future investigations.

Microvessel density has been shown to keep an inverse relationship to patient age at diagnosis, diameter, and extent of the primary tumor. ${ }^{13}$ This unexpected finding was thought to be explained by the previous findings that poorly-differentiated carcinomas exhibit smaller microvessel numbers. ${ }^{21,22,30}$ Accordingly, the present study revealed a tendency for the lowest MVD to exist in locally invasive tumors and in patients older than 45 years.

The Kaplan-Meier disease-free survival test was not appropriate because there was an insufficient number of patients in each group studied. Therefore, the AMES ${ }^{4}$ prognostic index was used, and we found that the MVD was not greater in the high-risk patient group. Livolsi and Asklen ${ }^{13}$ also found that decreased survival was not predicted by high microvessel counts. Perhaps this occurred because poorly differentiated carcinomas have low angiogenesis and are related to worse prognosis.

In our study, tumors in patients with recurrent disease tended to develop more angiogenesis. Fontanini et al. ${ }^{21}$ did not observe a significant relationship between prognosis and MVD. However, it should be noted that patients who died had a greater median MVD than surviviors. Using the European Organization Research on Treatment of Cancer (EORTC) prognostic index, Wong ${ }^{29}$ found an association between angiogenesis and prognosis in follicular carcinoma, but not in papillary carcinoma.

\section{CONCLUSION}

Our results suggest that angiogenesis is more intense among the classic and tall cell variants of metastatic tumors, showing that microvessel count can be an indicator of metastatic potential in these histological subtypes of papillary thyroid carcinoma.

Patients that developed recurrent disease had a tendency to exhibit higher angiogenesis; however, there was no association between MVD and prognostic index groups.

Finally, our data demonstrated the importance of the study of angiogenesis in papillary thyroid carcinoma.

\section{ACKNNOWLEDGEMENTS}

We are grateful to Professor João Carlos das Neves Pereira from the Thoracic Surgery Department of and Professor Anói Castro Cordeiro from the Surgery Department of Hospital das Clinicas, Faculty of Medicine, University of Sao Paulo (FMUSP) for continuous advice throughout the development of the investigation. We also thank Sandra de Moraes Fernezlian, Angela Batista dos Santos and Ana Lucia Garippo for careful and dedicated work in the immunohistochemical procedures and Renato Akira, for help with patients' registrations analysis.

This research was supported by CAPES.

\section{RESUMO}

Stabenow E, Tavares MR, AM Ab'Saber, ER Parra-Cuentas, LL de Matos, Eher EM et al. Angiogênese como indicador do potencial de metástase no carcinoma papilífero tireóideo. Clinics. 2005;60(3):233-40.

O desenvolvimento dos tumores depende da formação de neovasos, a angiogênese. Em algumas neoplasias, a alta densidade de microvasos tumorais correlaciona-se com a presença de metástase.

OBJETIVO: Determinar se a medida da angiogênese pode indicar o potencial de metástase e o prognóstico do carcinoma papilífero tireóideo.

MÉTODO: Foi feita análise retrospectiva de 30 tireoidectomizados, divididos em dois grupos de 15 indivíduos cada, respectivamente com e sem metástase. A partir dos blocos de parafina, foi calculada a densidade de microvasos no tecido tumoral por meio da quantificação da expressão do anticorpo CD34 pela imunohistoquímica. A associação da densidade de microvasos com a presença de metástase, ocorrência de recidiva e os grupos de risco do índice prognóstico AMES foi determinada por análise estatística.

RESULTADOS: A mediana da densidade de microvasos no grupo de doentes sem metástase (200,0 microvasos $/ \mathrm{mm}^{2}$ ) foi inferior àquela dos portadores de metástase $(254,4$ microvasos $\left./ \mathrm{mm}^{2}\right)(\mathrm{p}=.2)$, sem atingir significância estatística. Ao considerar apenas os subtipos histológicos clássico e de células altas, essa diferença tornou-se significante $(p=.02)$, uma vez que a variante folicular exibiu maior DMV que os demais subtipos, independente da presença de metástase. Houve tendência não significativa à maior densidade de microvasos entre aqueles que 
apresentaram recidiva $\left(294,4\right.$ microvasos $/ \mathrm{mm}^{2}$ contra 249,6 microvasos $/ \mathrm{mm}^{2}, \mathrm{p}=.11$ ). Nos grupos de baixo e alto risco, a mediana da densidade de microvasos foi de 304,0 microvasos $/ \mathrm{mm}^{2}$ e 229,6 microvasos $/ \mathrm{mm}^{2}$ respectivamente $(\mathrm{p}=.27)$.

CONCLUSÃO: A angiogênese foi mais intensa nos tumores com metástase nos subtipos clássico e de células altas, sugerindo que a contagem de microvasos pode ser um indicador do potencial de metástase nestes subtipos histológicos do carcinoma papilífero tireóideo. Doentes que evoluíram com recidiva tenderam a exibir maior angiogênese, porém não houve associação da densidade de microvasos e o índice prognóstico.

\section{UNITERMOS: Carcinoma papilífero tireóideo. Metástase linfonodal. Angiogênese. CD34. Prognóstico.}

\section{REFERENCES}

1. Hay ID, Bergstralh EJ, Goellner JR, Ebersold JR, Grant CS Predicting outcome in papillary thyroid carcinoma: development of a reliable prognostic scoring system in a cohort of 1779 patients surgically treated at one institution during 1940 through 1989. Surgery. 1993;114(6):1050-7; discussion 1057-8.

2. Asakawa H, Kobayashi T, Komoike Y, Tamaki Y, Matsuzawa Y, Monden M. Prognostic factors in patients with recurrent differentiated thyroid carcinoma. J Surg Oncol. 1997;64(3):202-6.

3. Mazzaferri EL, Jhiang SM. Long-term impact of initial surgical and medical therapy on papillary and follicular thyroid cancer. Am J Med. 1994;97(5):418-28.

4. Cady B, Rossi R. An expanded view of risk-group definition in differentiated thyroid carcinoma. Surgery. 1988;104(6):947-53.

5. Shaha AR, Shah JP, Loree TR. Patterns of failure in differentiated carcinoma of the thyroid based on risk groups. Head Neck. 1998;20(1):26-30.

6. Goldenberg JD, Portugal LG, Wenig BL, Ferrer K, Wu JC, Sabnani J. Well-differentiated thyroid carcinomas: p53 mutation status and microvessel density. Head Neck. 1998;20(2):152-8.

7. Folkman J. Tumor angiogenesis: therapeutic implications. N Engl J Med. 1971;285(21):1182-6.

8. Ye C, Feng C, Wang S, Liu X, Lin Y, Li M. Antiangiogenic and antitumor effects of endostatin on follicular thyroid carcinoma. Endocrinology. 2002;143(9):3522-8.

9. Hart IR, Saini A. Biology of tumour metastasis. Lancet. 1992;339(8807):1453-7.
10. Gimbrone MA, Jr., Leapman SB, Cotran RS, Folkman J. Tumor dormancy in vivo by prevention of neovascularization. J Exp Med. 1972;136(2):261-76.

11. Kolch W, Martiny-Baron G, Kieser A, Marme D. Regulation of the expression of the VEGF/VPS and its receptors: role in tumor angiogenesis. Breast Cancer Res Treat. 1995;36(2):139-55.

12. Senger DR, Van de Water L, Brown LF, Nagy JA, Yeo KT, Yeo TK, et al. Vascular permeability factor (VPF, VEGF) in tumor biology. Cancer Metastasis Rev. 1993;12(3-4):303-24.

13. Akslen LA, Livolsi VA. Increased angiogenesis in papillary thyroid carcinoma but lack of prognostic importance. Hum Pathol. 2000;31(4):439-42.

14. Dray TG, Hardin NJ, Sofferman RA. Angiogenesis as a prognostic marker in early head and neck cancer. Ann Otol Rhinol Laryngol. 1995;104(9 Pt 1):724-9.

15. Klein M, Picard E, Vignaud JM, Marie B, Bresler L, Toussaint B, et al. Vascular endothelial growth factor gene and protein: strong expression in thyroiditis and thyroid carcinoma. J Endocrinol. 1999;161(1):41-9.

16. Chen KT, Lin JD, Chao TC, Hsueh C, Chang CA, Weng HF, et al. Identifying differentially expressed genes associated with metastasis of follicular thyroid cancer by cDNA expression array. Thyroid. 2001;11(1):41-6.

17. Srivastava A, Laidler P, Davies RP, Horgan K, Hughes LE. The prognostic significance of tumor vascularity in intermediatethickness $(0.76-4.0 \mathrm{~mm}$ thick) skin melanoma. A quantitative histologic study. Am J Pathol. 1988;133(2):419-23. 
18. Weidner N, Folkman J, Pozza F, Bevilacqua P, Allred EN, Moore $\mathrm{DH}$, et al. Tumor angiogenesis: a new significant and independent prognostic indicator in early-stage breast carcinoma. J Natl Cancer Inst. 1992;84(24):1875-87.

19. Macchiarini P, Fontanini G, Hardin MJ, Squartini F, Angeletti CA. Relation of neovascularisation to metastasis of non-small-cell lung cancer. Lancet. 1992;340(8812):145-6.

20. Gasparini G, Weidner N, Maluta S, Pozza F, Boracchi P, Mezzetti $\mathrm{M}$, et al. Intratumoral microvessel density and p53 protein: correlation with metastasis in head-and-neck squamous-cell carcinoma. Int J Cancer. 1993;55(5):739-44.

21. Fontanini G, Vignati S, Pacini F, Pollina L, Basolo F. Microvessel count: an indicator of poor outcome in medullary thyroid carcinoma but not in other types of thyroid carcinoma. Mod Pathol. 1996;9(6):636-41.

22. Frigugliett IC, Mello ES, Castro IV, Filho GB, Alves VA. Metalloproteinase-9 immunoexpression and angiogenesis in thyroid follicular neoplasms: relation to clinical and histopathologic features. Head Neck. 2000;22(4):373-9.

23. Dhar DK, Kubota H, Kotoh T, Tabara H, Watanabe R, Tachibana $\mathrm{M}$, et al. Tumor vascularity predicts recurrence in differentiated thyroid carcinoma. Am J Surg. 1998;176(5):442-7.
24. Ishiwata T, Iino Y, Takei H, Oyama T, Morishita Y. Tumor angiogenesis as an independent prognostic indicator in human papillary thyroid carcinoma. Oncol Rep. 1998;5(6):1343-8.

25. Rosai J, Carcangiu M. AFIP, atlas of tumor pathology: tumors of the thyroid gland. Washington; 1992.

26. Gundersen HJ, Bendtsen TF, Korbo L, Marcussen N, Moller A, Nielsen K, et al. Some new, simple and efficient stereological methods and their use in pathological research and diagnosis. Apmis. 1988;96(5):379-94.

27. Vermeulen PB, Gasparini G, Fox SB, Toi M, Martin L, McCulloch $\mathrm{P}$, et al. Quantification of angiogenesis in solid human tumours: an international consensus on the methodology and criteria of evaluation. Eur J Cancer. 1996;32A(14):2474-84.

28. Fox SB. Tumour angiogenesis and prognosis. Histopathology. 1997;30(3):294-301.

29. Wong NA, Willott J, Kendall MJ, Sheffield EA. Measurement of vascularity as a diagnostic and prognostic tool for well differentiated thyroid tumours: comparison of different methods of assessing vascularity. J Clin Pathol. 1999;52(8):593-7.

30. Herrmann G, Schumm-Draeger PM, Muller C, Atai E, Wenzel B, Fabian T, et al. T lymphocytes, CD68-positive cells and vascularisation in thyroid carcinomas. J Cancer Res Clin Oncol. 1994;120(11):651-6. 